малопроницаемой для воды оболочке содержится значительное количество эфирных масел, фенолов и других веществ, затрудняющих доступ воды и воздуха к зародышуЭффективность намачивания семян зависит от температуры воды и продолжительности обработки. Результатом такой обработки семян является получение более ранних всходов и сокращение вегетационного периода.

\title{
Барботирование семян
}

Как наиболее эффективным и менее трудоёмким, по сравнению с намачиванием и проращиванием семян, является способ барботирования.

Для прорастания семян необходимы: влага, тепло и воздух. При достаточной температуре и влажности семя набухает, его клетки насыщаются водой и начинают функционировать. Обеспечить такие условия на начальной стадии развития растения, позволяет предпосевная подготовка семян барботированием.

Суть метода заключается в выдерживании семян в воде, постоянно аэрируемой путём подачи воздуха или кислорода. Название приёма происходит от устройств барботеров, в которых обрабатывают партии семян.

\section{Выводы}

Сокращение сроков появления всходов овощных культур имеет большое значение в агротехнике их производства. Ранние и дружные всходы менее подвержены угнетению сорняками, а так же способствуют более раннему формированию цветков и продуктивных органов у растений, что позволяет раньше получить урожай и в больших размерах. Проведенный обзор существующих способов предпосевной обработки семян позволил выделить как наиболее перспективный для тугорослых семян овощных культур барботирование, насыщение семян кислородом и водой.

$$
* * *
$$

1. Интернет ресурс: $h$ ttp://vseoede.net/?p=123

2. Практикум по овощеводству / Т.В. Соромотина; федеральное гос. бюджетное образов.учреждение высшего образов. «Пермская гос. с.-х. акад. им. акад. Д.Н. Прянишникова». - Пермь: ИПЦ «Прокрость», 2016. - 305 с. ISBN 978-5-94279-308-1

3. Кузнецов А.В. «Совершенствование предпосевной подготовки семян свеклы с обоснованием конструктивно-технологических параметров устройства для барботирования кислородом»: диссертация на соискание учёной степени кандидата технических наук - Н. Новгород, 2012

4. Интернет ресурc: http://www.sort-semena.ru/semana.html

\section{Чигирина А.B. \\ Развитие рынка земель сельскохозяйственного назначения}

Красноярский государственный аграрный университет (Россия, Красноярск)

doi:10.18411/lj-31-03-2018-81

idsp: 000001:lj-31-03-2018-81

\section{Аннотация}

Частная собственность на землю и рынок земли стали одной из наиболее противоречивых и дискутируемых тем аграрной экономики. То или иное решение этого вопроса зачастую является важнейшим фактором в решении аграрной проблемы в России. С одной стороны - попыткой найти за счет рынка земли средства для капиталовложений в сельское хозяйство, а с другой - продолжить приватизацию едва ли не самой главной составляющей национального богатства с повышением мобильности земельной собственности и реструктуризацией хозяйств.

Ключевые слова: рынок земли, земельный участок сельскохозяйственного назначения, виды сделок с земельными участками, землеустроительные работы. 
Современное состояние аграрной сферы страны отражается сокращением сельскохозяйственных угодий, посевных площадей, происходит вывод их из хозяйственного оборота, что приводит к снижению урожайности и валового сбора, к обострению продовольственной безопасности, поскольку, обладая огромным потенциалом ресурсов, наша страна превратилась в крупнейшего импортера продовольствия. Согласно статистическим данным на 1 января 2016 года площадь земель сельскохозяйственного назначения составила 383,7 млн. га (площадь земель данной категории в Республике Крым составила 1450,3 тыс. га). В сравнении с предшествующим годом площадь категории земель в составе земельного фонда Российской Федерации уменьшилась на 1,8 млн. га. Перечисленные факты вынуждают производителя вести экстенсивный путь развития, что приводит к потере конкурентоспособности отечественной продукции.

В настоящее время сельское хозяйство страны испытывает острую нехватку оборотных средств, что ведет к невозможности осуществления процесса расширенного воспроизводства. Недоступность из-за недостаточности залогового обеспечения долгосрочных кредитных ресурсов вынуждает хозяйства использовать краткосрочные, которые характеризуются более высокими ставками. Для создания доступности аграрного сектора к долгосрочным кредитам рассматривается возможность использования ипотеки земель сельскохозяйственного назначения, которые являются наиболее приемлемым вариантом залога. Однако решение данной задачи невозможно осуществить в полном объеме, поскольку есть ряд проблем, связанных с состоянием и развитием земельного рынка.

Земля, будучи основой деятельности и существования человека, является главным средством производства, важной частью материально-технической базы в сельском хозяйстве, и от того, насколько эффективно она будет использоваться, зависит достаток и достояние общества. Одно из главных предназначений земли - обеспечение потребности населения в сельскохозяйственных продуктах, а пищевой и перерабатывающей промышленности - в сырье.

Помимо того что земля выступает средством производства, в то же время она является объектом собственности, сферой приложения труда и капитала. Экономические отношения по поводу владения, распоряжения и пользования землей как главного средства производства в сельском хозяйстве относят к земельным отношениям. Земельные отношения должны затрагивать такие вопросы, как формы собственности, отношения эффективного использования земли, рынок земли, ренту, способы и методы регулирования земельных отношений. Развитие земельных отношений непосредственно связано с возникновением и развитием отношений собственности, в частности права частной собственности, которое понимается гораздо шире, чем просто владение, пользование и распоряжение.

Однако в России по вопросу воздействия форм собственности на землю и хозяйствования на эффективность использования земли существуют довольно противоречивые мнения.

Гражданский кодекс признает частную, государственную, муниципальную и иную формы собственности. Касательно вопроса собственности на землю сторонники частной собственности на землю аргументируют свою точку зрения тем, что в этом случае облегчается доступность к кредитным ресурсам под залог земли. Противники же выражают свои опасения по поводу того, что в этом случае земля может быть потеряна землевладельцами, что приведет к росту безработицы в сельской местности и, кроме того, бесконтрольному использованию земли.

Новая аграрная реформа, начатая в эпоху рыночных преобразований, определила основные направления своего осуществления:

- земельная реформа, предполагавшая приватизацию земли в частную и общую долевую собственность; 
- реорганизация колхозов и совхозов, приватизация государственных аграрных предприятий;

- приватизация предприятий сферы АПК.

Сторонники частной собственности на землю одержали верх, в результате чего возник рынок земель сельскохозяйственного назначения, который включает в себя все операции по продаже, аренде, обмену, передаче по наследству, уступкам прав, субаренде, временному пользованию, совместному использованию, операции с реальной земельной собственностью.

Хотя земельный рынок России постепенно развивается, тем не менее его существование зависит от различных факторов. Такими могут послужить нормативные акты органов власти, экономические и политические аспекты. Конкуренция на данном рынке пока слаба, и поэтому его существование пока достаточно далеко от совершенства. Как и любой рынок, рынок земли характеризуется наличием спроса и предложения, которые являются основными факторами установления цены на землю.

Отличительной особенностью земельного рынка является ограниченность предложения, поэтому при определении цены равновесия главную роль играют факторы спроса. При стабильном предложении земли повышение спроса приводит к увеличению цены, и, наоборот, сокращение спроса приводит к снижению цены. Если на других рынках при увеличении цены происходит повышение предложения, а сокращение цены приводит к его снижению, то предложение на земельном рынке остается стабильным. На данном рынке слабо прослеживается связь между изменением спроса и предложения.

Однако рыночный земельный оборот ограничен. И этому есть множество причин. Правовая база, сложившаяся на данный момент в России, должна была решить задачи целевого использования сельскохозяйственных угодий, учитывая интересы государства. Однако эффективность законодательных актов снижается отсутствием или неполным описанием в них четких механизмов реализации.

Так, закон «Об обороте земель сельскохозяйственного назначения» устанавливает право владельцев на совершение с земельными долями сделок и что право натакого рода сделки наступает только после выделения земельных долей в земельные участки. Однако в законе не были учтены трудности, связанные с организационными причинами и стоимостью работ в данном направлении. Таким образом, закон оказался противоречив: с одной стороны, он был ориентирован на развитие оборота земель, а с другой - высокая стоимость землеустроительных работ затруднила его реализацию в полном объеме.

Правовая база, регулирующая использование угодий, требует конкретизации основных актов. Так, необходимо на законодательном уровне усилить ответственность за нерациональное использование земель, разрушение почвенного покрова, а также стимулировать землепользователей эффективно использовать и охранять угодья.

Закон «Об обороте земель сельскохозяйственного назначения» предусматривает возможность принудительного изъятия земельных долей или участков в случае их нецелевого использования в течение двух и более лет. Впоследствии поправка к закону увеличила срок нецелевого использования до трех и более лет. Но, как показывает практика, земли могут пустовать и значительно большее время, и потому условие неиспользования земли в течение двух, трех и более лет к ним не применяется. Одной из главных причин этого является сама процедура изъятия земель через суд, которая сопровождается длительными затратами времени и бюрократическими проволочками. Показав свою неэффективность, данная процедура могла бы быть заменена, например, передачей решения об изъятии неиспользуемых угодий органам соответствующих уровней власти, что повлекло бы за собой более оперативное решение вопросов.

Следует отметить отсутствие и неэффективность должного контроля за состоянием и использованием земельных ресурсов со стороны государства и его органов на местах. Очевиден и тот факт, что слабо работает система стимулирования 
землепользователей в части проведения и соблюдения природоохранных и землесберегающих технологий. Причинами этого являются как слабая юридическая защищенность сельхозугодий, так и отсутствие должной финансовой поддержки государства в области землеохранных мероприятий.

Развитие земельного рынка невозможно без развития земельного оборота, который в рыночных условиях напрямую зависит от решения вопроса собственности на землю. Как уже было отмечено, собственниками земли являются государство, физические и юридические лица. Однако такое разделение прав на землю недостаточно для эффективного оборота земли, поскольку необходимы юридически правильно оформленные правоустанавливающие документы, которые бы дали возможность определить право юридических и физических лиц на земельную собственность. Следует отметить еще одну особенность рынка земли - поскольку объектом на нем является земля, то она требует своего разграничения, определения своих границ и земельной площади. Поэтому для того чтобы земельный рынок успешно развивался, важной задачей является решение вопросов землеустройства, к числу которых нужно отнести оценку собственности, определение границ и площади земельного участка, установление межевых знаков, выдачу соответствующих правоустанавливающих документов.

Проведение землеустроительных работ в современном сельском хозяйстве России остается одной из главных задач, требующих своего скорейшего решения. Практика показывает, что в большинстве случаев земли, находящиеся в пользовании товаропроизводителей, состоят из земель, относящихся к федеральным, региональным и муниципальным, частных и находящихся в общей долевой собственности. Из-за несовершенства оформления правовых документов на землю, неопределенности границ земельной собственности происходит искажение реального положения дел земельного оборота и купли-продажи прав на земельные участки.

Нерешенным остается вопрос, касающийся земельных долей. Необходимо отметить, что земельный рынок, земельный оборот в аграрном секторе России оказался неразрывно связан с крупными товаропроизводителями. В настоящее время значительную площадь обрабатываемых ими земель составляют именно земельные доли, не выделенные в натуре в земельные участки.

Актуален и вопрос выделения земельного участка в счет земельной доли. Вопервых, для проведения данной процедуры необходимо уточнять списки владельцев земельных долей (которых бывает довольно трудно найти), а затем оформить равный ей по площади земельный участок, местоположение которого нужно определить. Во-вторых, в одном и том же хозяйстве земли территориально разбросаны на значительные расстояния и имеют различнуюконтурность, что часто вызывает споры по поводу того, кому и какой участок достанется. В-третьих, в случае успешного решения вопроса выделения доли в земельный участок собственнику предстоит проделать серьезный объем работ, требующий временных и финансовых затрат, - провести межевание, установление границ, оформление картосхемы на земельный участок, паспортизацию, оформление правоустанавливающих документов, бонитировку почв, стоимостную оценку земель. Только после данных работ и получения правоустанавливающих документов земельный участок должен быть зарегистрирован в Едином государственном реестре прав, после чего с ним можно совершать сделки.

Кроме сложности выделения земельного участка в счет земельной доли существует и еще одна - дороговизна операций их проведения, особенно учитывая низкие доходы сельского населения и то, что во многих хозяйствах значительные площади не обрабатываются из-за отсутствия денежных средств. В этом направлении необходимо активизировать организационные и землеустроительные работы.

Таким образом, рассмотрев основные проблемы состояния и развития земельного рынка, нужно выделить основные, решение которых будет способствовать эффективному развитию рынка. 
Во-первых, земля является базисом производства сельхозпродукции. Намного экономичнее и эффективнее вести интенсивный путь обработки земель с использованием современной техники и технологий, что также будет вести к их охране за счет применения ресурсосберегающих технологий.

Во-вторых, государство должно вмешиваться в сферу земельных отношений, поскольку в целях сохранения продовольственной безопасности оно должно защищать сельское хозяйство и его земельную базу от нецелевого и нерационального использования, исключить возможность спекулятивных продаж земель сельскохозяйственного назначения.

В-третьих, оборот земельного рынка должен способствовать решению задач аграрной политики государства, а не являться тормозом его развития в силу своих особенностей. Для этого нужно усилить работу в области информационного обеспечения, консультационного обслуживания.

Очевидно и то, что без проведения масштабных землеустроительных работ невозможно будет обеспечить эффективное развитие земельного рынка в сельском хозяйстве страны. Это понимают в Министерстве сельского хозяйства России. В последнее время оно активизировало работу по регулированию оборота земель сельскохозяйственного назначения. Одним из основных направлений его работы является совершенствование земельного законодательства в части упрощения процедуры выделения земельных участков в счет земельных долей, установления четкого порядка отказа от права собственности на земельные доли, предлагается повысить ответственность пользователей в случае ненадлежащего использования земли. Кроме того, рассматривается возможность снижения затрат по оформлению и межеванию земельных участков путем софинансирования работ из федерального и регионального бюджетов. Однако как скоро решение этих задач осуществится на практике, пока неизвестно, но без их реализации эффективное и рациональное землепользование в аграрном секторе России будет затруднено.

$$
* * *
$$

1. Государственный (национальный) доклад «О состоянии и использовании земель в Российской Федерации в 2016 году». — М.: ФАКОН, 2017. — 274 с.

2. Федеральный закон «Об обороте земель сельскохозяйственного назначения» от $24.07 .2002 \mathrm{~N}$ 101-ФЗ// Справочно-правовая система «Консультант Плюс».

3. Панкова, К.И. Две земельные реформы - два разных результата / К.И. Панкова // Экономика сельскохозяйственных и перерабатывающих предприятий. - 2008. — № 9.

4. Сланкова, Л.Н. Земельные отношения: проблемы землепользования и землевладения / Л.Н. Сланкова // Экономика сельскохозяйственных и перерабатывающих предприятий. — 2007. — № 11. 